\title{
Antioxidant Potentials of morel mushroom (Morchella conica Pers.) from Nepal
}

\section{Jay Kant Raut ${ }^{1} \bowtie$, Minu Adhikari $^{1}$, Santoshi Bhushal ${ }^{1}$, Lok Ranjan Bhatt ${ }^{1}$}

${ }^{1}$ Nepal Academy of Science and Technology(NAST), Khumaltar, Lalitpur, Nepal

$$
\text { raut_jk2000@yahoo.com }
$$

\begin{abstract}
Oxidative stress contributes to the aging process and raises the risk of several chronic diseases. In recent years, natural antioxidants are being explored intensively for their ability to protect organisms and cells from oxidative stress-induced harm. Furthermore, mushrooms are widely used as a source of natural therapies for a variety of ailments caused by oxidative stress. In this study antioxidant activities of Morchella conica Pers. extracts obtained with methanol were investigated. This is supposed to be the first report of the antioxidant activity of morel mushroom from Nepal. Five complimentary test systems; namely DPPH free radical scavenging, total phenolic compounds, total flavonoid, ascorbic acid, and carotenoid concentration were used. At concentrations of $12.5,25,50,100$ and $200 \mu \mathrm{g} / \mathrm{ml}$ the methanol extracts scavenged 69, 69, 70, 68 and $81 \%$ DPPH radicals. The total phenolic content of the extracts was $4.304 \pm 0.12 \mathrm{mg} / \mathrm{g}$ gallic acid equivalent. The total flavonoid compound concentration was measured as $0.381 \pm 0.00 \mathrm{mg} / \mathrm{g}$ quercetin equivalent. The concentrations of ascorbic acid were recorded $19 \pm 0.02 \mathrm{mg} / \mathrm{g}$ dry sample. $\beta$-carotene and lycopene detected in the extract of $M$. conica are $0.020 \pm 0.001$ and $0.021 \pm 0.002 \mu \mathrm{g} / \mathrm{ml}$ respectively. Finally, the findings of this study demonstrated that $M$. conica has a high antioxidant activity, making it potentially effective in antioxidant therapy and therapeutic intervention in oxidative stress-related disorders.
\end{abstract}

Keywords:anti-aging, DPPH, healthcare, NTFP,nutraceutical, oxidative stress 


\section{INTRODUCTION}

Oxidation is an important process through which the human body transforms nutrients such as carbohydrates, fats, and proteins into energy to fuel biological processes. Oxygen $(\mathrm{O} 2)$ derived free radicals at low levels are necessary for maintaining normal cell functions, and the endogenous antioxidant defense systems of the body can avert any harmful effects. However, the production of oxygen-derived free radicals at high concentrations results in the onset of many diseases like cancer, rheumatoid arthritis, atherosclerosis, premature aging, neural disorders such as Alzheimer and Parkinson. Apart from the endogenous antioxidant defense mechanisms of an organism, its dietary intake is another very important source of antioxidants and may contribute to oxidative homeostasis(Kozarski et al., 2015). Antioxidant supplements or antioxidantcontaining foods may be used to help the organism to reduce oxidative damage. As in food, antioxidants are extensively also used in health care, anti-aging, and cosmetics products. In recent years, the restriction on the use of synthetic antioxidants, such as butylated hydroxyanisole (BHA) and butylated hydroxytoluene (BHT), has caused a rapidly increased interest in natural antioxidant substances (Ferreira et al., 2009; Kozarski et al., 2014). Preventive medicine and the food industry have shown an increased interest in the development of natural antioxidants. This could explain why there is currently much research on the antioxidant properties of natural products such as mushrooms.

Many mushrooms have been reported to possess antioxidant properties, which enable them to neutralize free radicals. Nowadays edible mushrooms have attracted attention as a commercial source of antioxidants (Ferreira et al., 2009; Khatua et al., 2013; Kozarski et al., 2014). They might be used directly in the enhancement of antioxidant defenses through dietary supplementation to reduce the level of oxidative stress. There is a wealth of evidence to support the effectiveness of such a strategy in vitro. Antioxidant potential in mushrooms has been found higher than in most vegetables and fruits (Sanchez, 2017). 


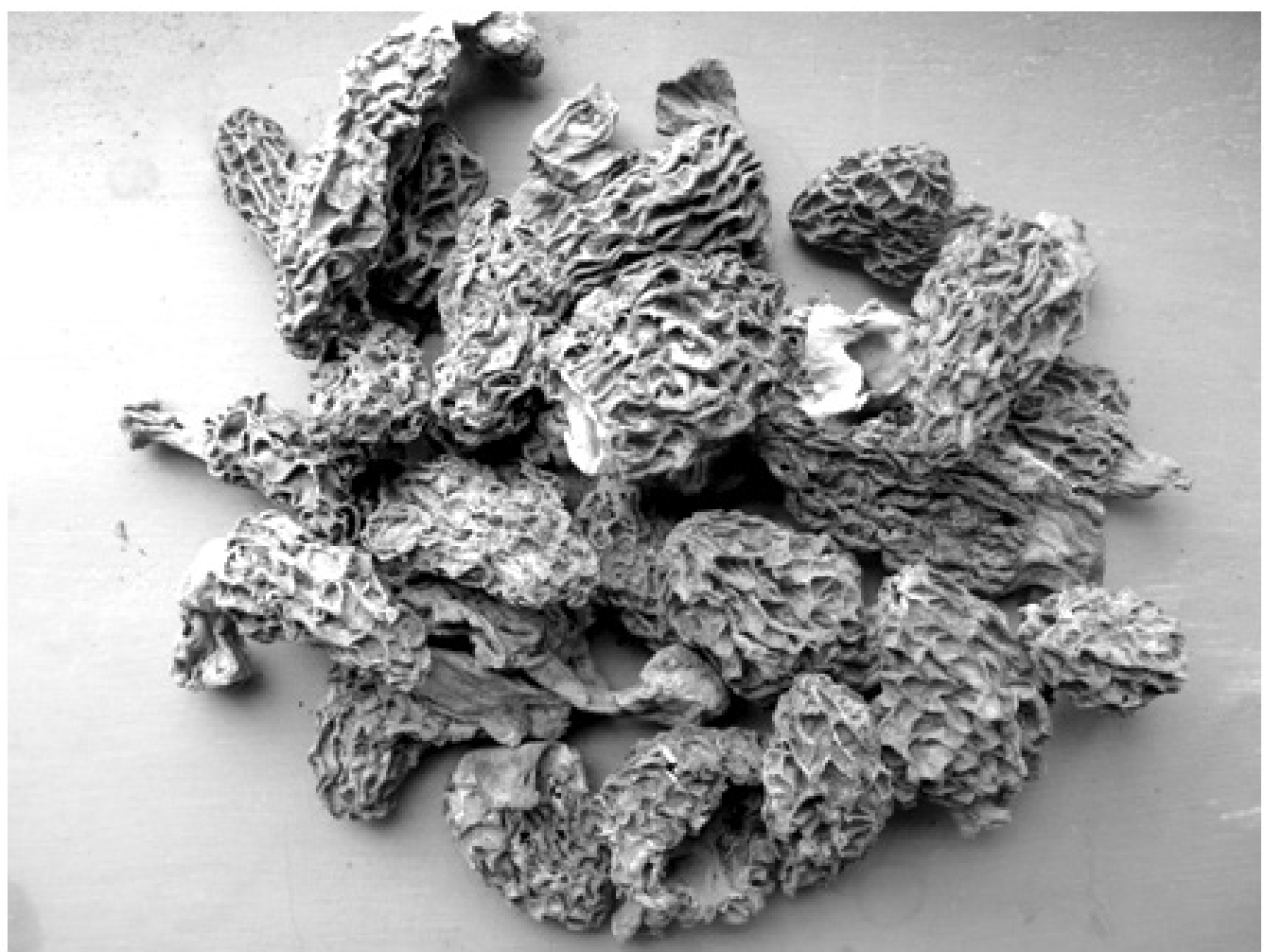

FIG. 1.Dry morel mushroom samples collected from trader's stock of Gorkha district.

For their rich, unique aroma, delicate flavour, and meaty texture, morels (Morchella spp.) are particularly appreciated in many cuisines (Tietel \& Masaphy, 2018). The Ministry of Forest and Soil Conservation of Nepal has designated them as an important and prioritized NTFP to be collected from forests (DPR, 2006). Wild morels are economically gathered and exported in large quantities from west Nepal, particularly from Karnali and Far west provinces, which account for 58 percent and 29 percent of total national output, respectively. It is extremely important to the Himalayan people who live near the forest. Morels have become the main source of cash income for the poorest households in certain locations (Subedi, 2001; Christensen \& Larsen 2005). According to Christensen \& Larsen (2005), 1.7 to 6.5 tons of dried morels are exported each year (fig. 1). Morels are sold under the brand name Himalayan Mushrooms, and a little royalty of NRs. $300 / \mathrm{kg}$ generates a large amount of cash for the state.M. conica and M. esculenta are the most regularly encountered and traded species (Raut et al., 2019; Subedi, 2001). Prices differ depending on the species. M. conica is always more 
expensive than other species. To date, Nepal has documented six species of Morchella (M. angusticeps, M. elata (= M. conica), M. esculenta, M. smithiana, M. umbrina, and M. vulgaris) (Adhikari, 2014). Nepalese morels are traded as a whole, with no species distinction. Morels, on the other hand, have a wide range of bioactivities. There are several studies on the antioxidant activity of morels from various nations, including India, Pakistan, Taiwan, Turkey, Portugal, and Serbia(Mau et al., 2004; Elmastas et al., 2006; Puttaraju et al., 2006; Heleno et al., 2013; Farrukh et al., 2017). However, the antioxidant activity of morels from Nepal is still unexplored. The trophic states, morphologies, high genetic diversity, and diverse habitats of Morchella species may alter the production of bioactive metabolites. Thus, the purpose of this study is to examine theantioxidant potential of $M$. conica from Nepal.

\section{MATERIALS AND METHODS}

\section{Collection of mushroom specimens and sample preparation}

Morel mushroom samplewas collected from trader's stockin Gorkha district (fig. 1). There was no single species in the sample. It was made up of more than two different species. TheMorchella conica was separated from the rest of the sample by its elongated, substantially upward attenuated pileus with acute apex.Specimens were confirmed based on macroscopic and microscopic descriptions available in the standard literature (Arora, 1996; Singer, 1996).Species names and author's abbreviations are annotated according to the international fungal database, the Index Fungorum (www. indexfungorum.org). For the antioxidant activities the dried samples were grinded to make fine powder and stored in the air-tight containers prior to further analysis.

\section{Methanolic extract}

For methanolic extract preparation $1 \mathrm{~g}$ of sample was weighed and soaked with 20 $\mathrm{ml}$ of Methanol. The mixture was kept in shaking incubator (to enhance extraction efficacy) on $100 \mathrm{RPM}$ (revolution per minute) at $37^{\circ} \mathrm{C}$ for 24 hours. Then the mixture was filtered with Whatman's No. 1 filter paper and the residue was again soaked with $20 \mathrm{ml}$ of methanol and above procedure was repeated for another 24 hours. Final volume of sample was made $40 \mathrm{ml}$ with addition of extra methanol and stored for determination of different parameters. 


\section{Antioxidant activity}

Antioxidant activity of sample was estimated using free radical scavenging activity of DPPH (2, 2-Diphenyl-1-Picrylhydrazyl) solution as described by Choi et al. (2002) with some modifications. Different concentrations of sample $(1-25 \mathrm{mg} / \mathrm{ml})$ were mixed with $0.3 \mathrm{mM}$ concentration of methanolic solution of $\mathrm{DPPH}$ in 1:1 ratio. The mixture was incubated in dark for 30 minutes at room temperatures and absorbance was measured at wave length of $517 \mathrm{~nm}$. DPPH solution and methanol were taken as positive and negative control respectively. L- ascorbic acid was taken as standard solution $(10-100 \mu \mathrm{g} / \mathrm{ml})$. Percentage free radical scavenging of sample was calculated as follows:

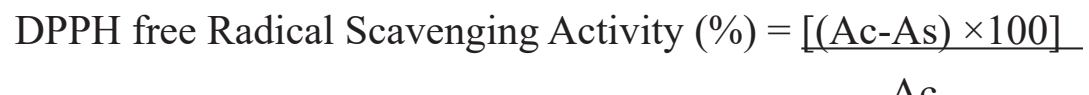
Ac Where Ac is absorbance of control and As is absorbance of sample respectively.

\section{Total Flavonoid content}

Total flavonoid content (TFC) of sample was determined by using Chang et al. (2002) with slight modification. In brief, $100 \mu \mathrm{l}$ of $5 \mathrm{mg} / \mathrm{mL}$ of methanolic extract of each sample was poured in 96 well ELISA plates and $100 \mu \mathrm{l}$ of $2 \%$ Aluminium chloride $\left(\mathrm{AlCl}_{3}\right)$ was added to it. The set up was incubated in dark for an hour and absorbance was measured at $415 \mathrm{~nm}$ in ELISA plate reader. TFC was expressed as mg Quercetin equivalent per gram of sample.

\section{Total Phenolic content}

Total phenolic content (TPC) of sample was determined by using Folin-Ciocalteu reagent (Singleton \& Rossi, 1965) with slight modification. Briefly, $30 \mu 1$ of methanolic extract of sample was poured in 96 well ELISA plates with $150 \mu 1$ Folin Ciocalteu (10\%) reagent and $120 \mu \mathrm{l}$ of $7.5 \%$ Sodium carbonate $\left(\mathrm{Na}_{2} \mathrm{CO}_{3}\right)$. The mixture was incubated for half an hour in dark and absorbance was measured at $765 \mathrm{~nm}$. Total Phenolic content of sample was expressed as mg Gallic Acid equivalent per gram of sample.

\section{Total Carotenoid content}

Total carotenoid content was determined by the method as described earlier (Nagata \& Yamashito, 1992) using spectrophotometric method. In brief, $0.1 \mathrm{~g}$ of dry powdered 
sample was vigorously shaken with $10 \mathrm{ml}$ of Acetone- Hexane (4:6) for 1 minute to enhance the efficacy of extraction. Then it was filtered through Whatman's no. 1 filter paper and filtrate was used for the measurement of absorbance at 453, 505, 645 and 663 $\mathrm{nm}$. Content of $\beta$ - carotene and lycopene were measured using following equations:

Content of $\beta$-carotene $=0.216 \mathrm{~A} 663-0.304 \mathrm{~A} 505+0.452 \mathrm{~A} 453$

Content of lycopene $=0.0458 \mathrm{~A} 663+0.372 \mathrm{~A} 505-0.0806 \mathrm{~A} 453$

Total $\beta$ - carotene and lycopene were expressed as $\mathrm{mg} / \mathrm{g}$ of sample.

\section{Vitamin $C$ content}

Total vitamin $\mathrm{C}$ content was measured by following earlier described method (Klein \& Perry, 1982) with minor modification as suggested by Hegazy et al. (2013). Briefly, $200 \mathrm{mg}$ of sample was mixed with $2 \mathrm{ml}$ of $1 \%$ metaphosphoric acid solution and kept for 45 minutes at room temperature. The extraction was filtered through Whatman's no.1 filter paper and filtrate were used for vitamin $\mathrm{C}$ estimation. Then 2,6- dichlorophenolindophenol (DCPIP) was mixed with extracted sample in 9:1 ratio and absorbance were measured at $515 \mathrm{~nm}$ against blank. L-ascorbic acid was taken as standard (10-100 $\mu \mathrm{g} / \mathrm{ml})$ and amount of vitamin C content was expressed as $\mathrm{mg}$ ascorbic acid per gram of sample.

\section{RESULTS AND DISCUSSION}

\section{DPPH radical scavenging activity}

Antioxidant activity of sample extract at different concentrations was determined using DPPH method. The DPPH is a stable organic free radical with an absorption maximum band around 515-528 nm (Stankovic, 2011) and is widely used for evaluation of antioxidant potential of compounds. At concentrations of 12.5, 25, 50, 100 and 200 $\mu \mathrm{g} / \mathrm{ml}$ the extract scavenged 69, 69, 70, 68 and 81\% DPPH radicals (fig. 2). The results obtained revealed that $M$. conica exhibits high antioxidant activity. These activities of the extract would make it potentially useful in antioxidant therapy and in therapeutic intervention in diseases involving oxidative stress. 
At $500 \mu \mathrm{g} / \mathrm{ml}$ concentration, the DPPH scavenging activity was $85.2 \pm 0.371 \%$ of methanolic extracts of $M$. esculenta collected from the Northwest Himalayan region of Shimla, India (Thakur \& Lakhanpal, 2014). Likewise, the maximum antioxidantactivity $(93.53 \pm 0.01)$ wasobserved with the concentration $3000 \mathrm{ppm}$ methanolicsolution of the water extract of Morchella conica collectedfrom Swat valley, Pakistanwhereas minimum antioxidant activity (44.86 \pm 0.94$)$ was observed with the concentration 100ppm (Farukh et al., 2017). M. conicamethanol extract from turkey showed a high antioxidant activity, being able to scavenge more than $80 \%$ of the DPPH radical at concentrationof $4.5 \mathrm{mg} / \mathrm{ml}($ Gursoy et al., 2009).

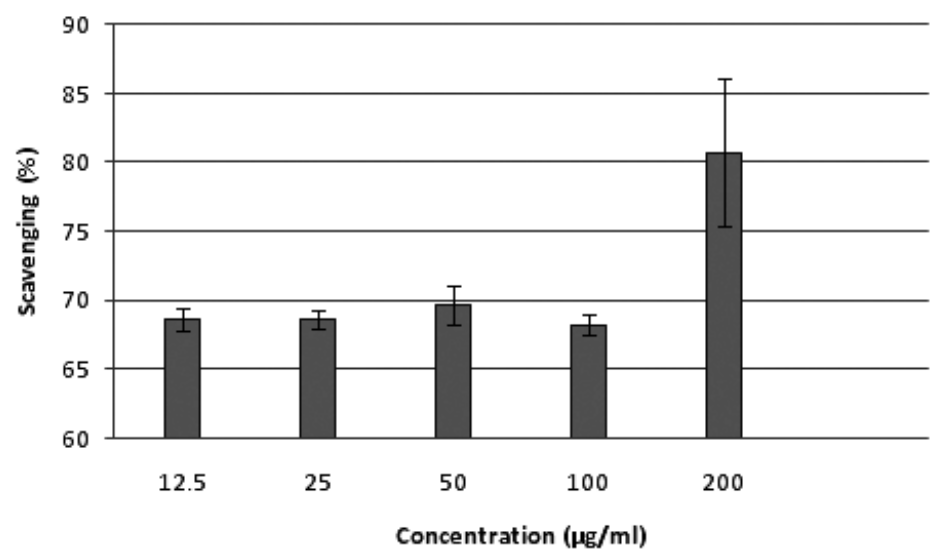

FIG. 2.Scavenging activity (\%) on DPPH radicals of mushroom methanolicextracts. Each value is expressed as mean \pm standard deviation( $n=$ 3). Bar represents standard deviation.

\section{Phenolic compounds}

Phenolic compounds include phenolic acids, flavonoids, hydroxybenzoic acids,hydroxycinnamic acids, lignans, tannins, stilbenes and oxidized polyphenols. Some of them stimulate synthesis of endogenous antioxidant molecules in the cell. It has beenreported that phenolic compounds exhibit antioxidant activity in biological systems, acting as free radical inhibitors, peroxide decomposers, metal inactivators or oxygen scavengers (Sanchez, 2017). Mushrooms contain large amounts of polyphenols at concentrations in the range of $6.25-3.62 \mathrm{mg} / \mathrm{ml}$ (Ramesh\& Pattar 2010; Sanchez 2017). The total phenolic content of methanolic extracts of $M$. conica in this study 
was $4.304 \pm 0.12 \mathrm{mg} / \mathrm{g}$ gallic acid equivalents.It has been reported that grapes and wine contain between 1.0 and $1.8 \mathrm{mg} / \mathrm{ml}$ of these compounds (Macheix et al., 1990). It is suggested that polyphenolic compounds have inhibitory effects on mutagenesis and carcinogenesis in humans, when up to $1.0 \mathrm{~g}$ is ingested daily from a diet rich in fruits and vegetables (Turkoglu, 2006)

\section{Flavonoids}

Flavonoids represent a large group of phenolic compoundswith antioxidant activity, that occur naturally inplants and are found in fruits, vegetables, grains, barks,roots, stems, flowers, and derived products like tea and wine.These compounds have been linked to reduce the risk of majorchronic diseases (Liu, 2004).Flavonoids have been shown to be highly effective scavengers of most types of oxidizing molecules, including singlet oxygen and various free radicals, which are possibly involved in DNA damage and tumor promotion (Wright, 2001). The total flavonoid compound concentration was measured as $0.381 \pm 0.00 \mathrm{mg} / \mathrm{g}$ quercetin equivalent.

\section{TABLE 1. Total flavonoid, phenolic, Carotenoid and Vitamin $C$ content of the mushroom extract.}

\begin{tabular}{|l|c|c|c|c|c|}
\hline Mushroom & $\begin{array}{c}\text { Flavonoid } \\
\text { content } \\
(\mathrm{mg} / \mathrm{g})\end{array}$ & $\begin{array}{c}\text { Phenolic con- } \\
\text { tent }(\mathrm{mg} / \mathrm{g})\end{array}$ & $\begin{array}{c}\beta \text { carotene } \\
(\mu \mathrm{g} / \mathrm{ml})\end{array}$ & $\begin{array}{c}\text { Lycopene } \\
(\mu \mathrm{g} / \mathrm{ml})\end{array}$ & $\begin{array}{c}\text { Vitamin } \\
\text { C content } \\
(\mathrm{mg} / \mathrm{g})\end{array}$ \\
\hline M. conica & $0.381 \pm 0.00$ & $4.304 \pm 0.12$ & $0.020 \pm 0.001$ & $0.021 \pm 0.002$ & $0.19 \pm 0.02$ \\
\hline
\end{tabular}

Each value is expressed as mean \pm standard deviation $(n=3)$

\section{Ascorbic acid}

Ascorbic acid, also known as vitamin $\mathrm{C}$ is a necessary nutrient for a limited number of animals, including humans, which are incapable of its synthesis and must secure by means of dietary uptake. In addition, ascorbic acid is thought to exert a protective role against various oxidative stress-related diseases such as heart disease, stroke, cancer, several neurodegenerative diseases and cataractogenesis (Halliwell, 1996). It was found in several mushroom species. The concentrations of ascorbic acid in the methanolic extracts of $M$. conica was recorded $19 \pm 0.02 \mathrm{mg} / 100 \mathrm{~g}$ DW. Grangeia et al. (2011) found high concentrations of ascorbic acid in the methanolic extracts of 
different saprotrophic and mycorrhizal wild edible mushrooms $(81.32-400.36 \mathrm{mg} / 100$ g DW). Kozarski et al. (2015) found $100 \mathrm{mg} / 100 \mathrm{~g}$ dry weight (DW) of ascorbic acid in the methanolic extract of the wild edible mushroom Cantharellus cibarius. It was higher than its content in some fruits and vegetables which are usually recommended as a good source of vitamin C (Davey et al., 2000). Ramesh \& Pattar (2010) reported that mushrooms contain vitamin $\mathrm{C}$ at concentrations in the range of $0.15-0.06 \mathrm{mg} / \mathrm{ml}$. Orange juice contains around $0.37 \mathrm{mg}$ of vitamin C/ml(Sanchez, 2017).

\section{Carotenoids}

$\beta$-carotene and lycopene

$\beta$-carotene and lycopene are natural pigments found in vegetables, fruits and mushrooms. They are also known as carotenoids which are synthesized by plants and microorganisms but not animals. Fruits and vegetables constitute the major sources of carotenoids in human diet.M. conica possess the significant carotenoid (table 1). $\beta$-carotene and lycopene detected in Lentinus squarrolosus, were in abundance compared to the concentration reported in some vegetables e.g., carrot, persimmon and tomato (Hussein et al., 2015)

Antioxidant activity of the morel mushrooms has significant importance because this activity greatly contributes to their nutraceutical properties, thus enhancing their nutritional and trade value. The result obtained from the antioxidant activity analysis of $M$. conica fulfills the gaps to evaluate its role on rural livelihood and the diet of people in a more scientific way. Based on the results, it is suggested that extracts of the mushroom species evaluated here could be of use as an easily accessible source of natural antioxidants. However, at present, the active components in the extracts, responsible for the observed antioxidant activity, are unknown. Further work is necessary on the isolation and purification of the active components from crude extracts of mushrooms to ascertain their mode of action. To the best of our knowledge, this is the first report of the antioxidant activity of morel mushrooms from Nepal. The mushroom can be incorporated into our food regime, representing an alternative source of food to prevent damage caused by oxidation in the human body. Therefore, $M$. conica can be harnessed in the management of oxidative stress-induced diseases since phenols, ascorbic acid, carotenoid, and flavonoid have been shown to possess various antioxidant functions. 


\section{ACKNOWLEDGEMENTS}

Authors are very grateful to Nepal Academy of Science \& Technology (NAST) for providingall kinds of support to conduct this work. The members of Natural Product Chemistry and Molecular Biotechnology Unit aregreatly acknowledged for their kind cooperation.

\section{REFERENCES}

ADHIKARI, M K (2014) Mushrooms of Nepal. Durrieu,G. \&Cotter,HVT(eds). KS Adhikari, Kathmandu, Nepal; 340p.

ARORA, D (1996) Mushroom demystified: A comprehensive guide to the fleshy fungi. Berkeley Ten speed press.

CHANG, C C; YANG, M H; WEN, H M; CHERN, J C (2002) Estimation of total flavonoid content in propolis by two complementary colorimetric methods. Journal of Food and Drug Analysis10(3): 178-182.

CHOI, C W; KIM, S C; HWANG, S S; CHOI, B K; AHN, H J; LEE, M Y; PARK, S H; KIM, S K (2002) Antioxidant activity and free radical scavenging capacity between Korean medicinal plants and flavonoids by assay-guided comparison. Plant Science 163: 1161-1168.

CHRISTENSEN, M; LARSEN, H O (2005) How can collection of wild edible fungi contribute to livelihoods in rural areas of Nepal? Journal of Forest and Livelihood 4: 50-55.

DAVEY, M W; VAN MONTAGU, M; INZE, D; SANMARTI, M; KANELLIS, A; SMIRNOFF, N; BENZIE, I J J; STRAIN, J J; FAVELL, D; FLETCHER, J (2000) Plant L-ascorbic acid: chemistry, function, metabolism, bioavailability and effects of processing. Journal of the Science of Food and Agriculture 80: 825-860.

DPR (2006) Prioritized NTFPs for economic development of Nepal. Department of Plant Resources, Thapathali, Kathmandu, Nepal. 
ELMASTAS, M; TURKEKUL, I; OZTURK, L; GLUCIN, I; ISILDAK, O; ABOUL-ENEIN, H Y (2006) Antioxidant activity of two wild edible mushrooms (Morchella vulgaris and Morchella esculenta) from North Turkey. Combinatorial Chemistry \&High Throughput Screening9: 443-448.

FARRUKH, S; IQBAL, Z; IQBAL, M; IRSHAD, S; HAMID, F S; WAHEED, A; ASLAM, S; BASHIR, M; ALI, S (2017) Antioxidant activity of Morchella conica collected from Swat Valley. Asian Journal of Advances in Agricultural Research 3(3): 1-5

FERREIRA， I; BARROS， L; ABREU， R (2009) Antioxidants in wild mushrooms. Current Medicinal Chemistry 16(12):1543-1560. https://doi. org/10.2174/092986709787909587

GRANGEIA, C; HELENO, S A; BARROS, L; MARTINS, A; FERREIRA, I, C F $\mathrm{R}$ (2011) Effects of trophism on nutritional and nutraceutical potential of wild edible mushrooms. Food Research International 44: 1029-1035.

GURSOY N, SARIKURKCU C, CENGIZ M, SOLAK M H (2009) Antioxidant activities, metal contents, total phenolics and flavonoids of seven Morchella species. Food and Chemical Toxicology47(9): 2381-2388.

HALliWELL, B (1996) Antioxidants in human health and disease. Annual Review of Nutrition 16:33-50.

HEGAZY,A; ROWAILY, S L; FAISAL, M;ALATAR, AA; BANA, M I; ASSAEED, A M (2013) Nutritive value and antioxidant activity of some edible wild fruits in the middle east. Journal of Medicinal Plant Research 7(15): 938-946.

HELENO, S A; STOJKOVIC, D; BARROS, L; GLAMOCLIJA, J; SOKOVIC, M; MARTINS, A (2013) A comparative study of chemical composition, antioxidant and antimicrobial properties of Morchella esculenta (L.) Pers. from Portugal and Serbia. Food Research International 51: 236-243. 
HUSSEIN, J M; TIBUHWA, D D; MSHANDETE, A M; KIVAISI, A K (2015) Antioxidant properties of seven wild edible mushrooms from Tanzania. African Journal of Food Science 9(9): 1-9.

KHATUA, S; PAUL, S; ACHARYA, K (2013) Mushroom as the potential source of new generation of antioxidant: A review. Research Journal of Pharmacy and Technology 6(5): 496-505.

KLEIN, B P; PERRY, A K (1982) Ascorbic acid and vitamin A activity in selected vegetables from different geographical areas of the United States. Journal of Food Science47(3): 941-945.

KOZARSKI, M; KLAUS, A; JAKOVLJEVIC, D; TODOROVIC, N; VUNDUK, J; PETROVIĆ, P; NIKSIC, M; VRVIC, M M; GRIENSVEN, L V (2015) Antioxidants of edible mushrooms. Molecules 20: 19489-19525; doi:10.3390/ molecules201019489.

KOZARSKI, M S; KLAUS, A S; NIKŠIĆ, M P; VAN GRIENSVEN, J L D; VRVIĆ, M M; JAKOVLJEVIĆ, D M (2014) Polysaccharides of higher fungi: biological role, structure and antioxidative activity. Hemijska Industrija 68(3): 305-320. https://doi.org/10.2298/HEMIND121114056K.

LIU, R H (2004) Potential synergy of phytochemicals in cancer prevention: mechanism of action. Journal of Nutrition 134: 3479-3485.

MACHEIX, J J; FLEURIET, A; BILLOT, J (1990) Fruit phenolics. FL, USA: CRC Press, Taylor and Francis Group; 1990.

MAU, J L; CHANG, C N; HUANG, S J; CHEN, C C (2004) Antioxidant properties of methanolic extracts from Grifola frondosa, Morchella esculenta and Termitomyces albuminosus mycelia. Food Chemistry 87: 111-118.

NAGATA, M; YAMASHITA, I (1992) Simple methodfor simultaneous determination of chlorophyll and carotenoids in tomato fruit. Nippn Shokuhin Kogyo Gakkaish39(10): 925-928. 
PUTTARAJU, N G; VENKATESHAIAH, S U; DHARMESH, S M; URS, S M; SOMASUNDARAM, R (2006) Antioxidant activity of indigenous edible mushrooms. Journal of Agricultural and Food Chemistry 54: 9764-9772.

RAMESH, C; PATTAR, M G (2010) Antimicrobial properties, antioxidant activity and bioactive compounds from six wild edible mushrooms of Western Ghats of Karnataka, India. Pharmacognosy Research 2:107-112.

RAUT, J K; UPADHYAYA, J; RAGHAVAN, V; ADHIKARI, M; BHUSHAL, S; SAINJU, P; GURMACHHAN, M C; GIRI, A; BHATT, L R (2019)Trade and conservation of morel mushrooms in Nepal. International Journal of Natural Resource Ecology and Management, 4(6):183-187. https://doi.org/10.11648/j. ijnrem.20190406.14.

SANCHEZ, C (2017) Reactive oxygen species and antioxidant properties from mushrooms. Synthetic and Systems Biotechnology 2: 13-22.

SINGER, R (1996) The agaricales in modern taxonomy. Bishan Singh Mahendrapal Singh, Dehradun (India).

SINGLETON, V L; ROSSI, J A (1965) Colorimetry of total phenolics with phosphomolybdic- phosphotungstic acid reagents. American Journal of Enology and Viticulture 16: 144-158.

STANKOVIC, M S (2011) Total phenolic content, flavonoid concentration and antioxidant activity of Marrubium peregrinum L. extracts. Kragujevac Journal of Science 33: 63-72.

SUBEDI, B P (2001) Plant profile: morel mushrooms. Himalayan Bioresources. 5. ANSAB, Kathmandu. 12-13.

THAKURI, M; LAKHANPAL, T N (2014) Qualitative phytochemical screening, total phenolic content and in vitro antioxidant activity in methanolic extracts of Morchella esculenta Fr. Proceedings of the $8^{\text {th }}$ International Conference on Mushroom Biology and Mushroom Products (ICMBMP8) 
TIETEL, Z; MASAPHY, S (2018) True morels (Morchella) nutritional and phytochemical composition, health benefits and flavor: A review. Critical Reviews in Food Science and Nutrition 58(11): 1888-1901. https://doi.org/10. 1080/10408398.2017.1285269.

TURKOGLU A (2006) Antioxidant and antimicrobial activities of Morchella conica Pers. African Journal of Biotechnology 5(11): 1146-1150.

WRIGHT, J S; JOHNSON, E R; DILABIO, G A (2001) Predicting the activity of phenolic antioxidants: theoretical method, analysis of substituent effects, and application to major families of antioxidants. Journal of the American Chemical Society 123: 1173-1183. 